\title{
Felbamate block of recombinant $N$-methyl-D-aspartate receptors: selectivity for the NR2B subunit
}

\author{
T. Patrick Harty ${ }^{1}$, Michael A. Rogawski * \\ Neuronal Excitability Section, Epilepsy Research Branch, National Institute of Neurological Disorders and Stroke, \\ National Institutes of Health, Building 10, Room 5N-250, 10 Center Drive MSC 1408, Bethesda, MD 20892-1408, USA
}

Received 19 July 1999; received in revised form 27 September 1999; accepted 4 October 1999

\begin{abstract}
The anticonvulsant felbamate blocks $N$-methyl-D-asparate (NMDA) receptors but fails to exhibit the neurobehavioral toxicity characteristic of other NMDA receptor antagonists. To investigate the possibility that felbamate's favorable toxicity profile could be related to NMDA receptor subtype selectivity, we examined the specificity of felbamate block of recombinant NMDA receptors composed of the NR1a subunit and various NR2 subunits. Felbamate produced a rapid, concentration-dependent block of currents evoked by $50 \mu \mathrm{M}$ NMDA and $10 \mu \mathrm{M}$ glycine in human embryonic kidney 293 cells expressing the rat NR1a subunit, and either the NR2A, NR2B or NR2C subunits; the $\mathrm{IC}_{50}$ values for block were $2.6,0.52$ and $2.4 \mathrm{mM}$, respectively (holding potential, $-60 \mathrm{mV}$ ). The Hill coefficient values were $<1$ and, in kinetic analyses, onset and recovery from block were well fit by double exponential functions, indicating binding to more than one blocking site on the NMDA receptor channel complex. The higher affinity of felbamate block of NMDA receptors containing the NR2B subunit could be accounted for by more rapid association and slower dissociation from these sites. We conclude that felbamate exhibits modest selectivity for NMDA receptors composed of NR1a/NR2B subunits. This selectivity could, in part, account for the more favorable clinical profile of felbamate in comparison with NMDA receptor antagonists that do not show subunit selectivity. (C) 2000 Elsevier Science B.V. All rights reserved.
\end{abstract}

Keywords: Felbamate; NMDA receptor; NR2 subunit; Voltage-clamp recording

\section{Introduction}

$N$-Methyl-D-asparate (NMDA) receptor antagonists were originally demonstrated to possess

\footnotetext{
* Corresponding author. Tel.: + 1-301-496-8013; fax: + 1301-402-6788.

E-mail address: rogawski@nih.gov (M.A. Rogawski)

${ }^{1}$ Present address: Cognetix Inc., 158 Main Street, Ivoryton, CT 06442, USA.
}

anticonvulsant activity by Croucher et al. (1982). Since this original report, NMDA receptor antagonists have been found to exhibit a broad spectrum of anticonvulsant activity in animal seizure models and also to protect against kindling development (Rogawski, 1992). The anticonvulsant and antiepileptogenic actions of NMDA receptor antagonists have engendered considerable interest in the potential utility of this class of drugs in 
epilepsy therapy. However, in clinical trials, NMDA receptor antagonists have demonstrated unacceptable neurobehavioral side effects that have precluded further development (Rogawski, 1998). To date, the only marketed anticonvulsant agent that exhibits NMDA receptor blocking activity at clinically relevant doses is the 1,3-propanediol dicarbamate felbamate (De Sarro et al., 1994; Rho et al., 1994; Pisani et al., 1995; Subramaniam et al., 1995; Corradetti and Pugliese, 1998). Although felbamate has idiosyncratic hematologic and hepatic toxicities that limit its use as a first-line agent (Pellock and Brodie, 1997), the drug nevertheless serves as an example of a clinically effective anticonvulsant with NMDA receptor blocking activity that possesses a low incidence of central nervous system side effects. The basis for felbamate's more favorable toxicity profile in comparison with other NMDA antagonists is not well understood. One attractive hypothesis is that felbamate could selectively target a subclass of NMDA receptors.

NMDA receptors in mammalian neurons are believed to be heterooligomers formed by coassembly of an obligatory NR1 subunit and at least one type of NR2 subunit (Dingledine et al., 1999). Four NR2 subunits have been identified, each of which exhibits a distinct regional distribution and developmental expression pattern. The four distinct NR2 subunits confer unique pharmacological and biophysical properties upon the NMDA receptors from which they are assembled.

To explore the possibility that felbamate's favorable toxicity profile could relate to subtype specificity, we examined its selectivity for block of recombinant NMDA receptors expressed in human embryonic kidney (HEK) 293 cells. Our results demonstrate that felbamate has modest selectivity for NMDA receptors containing the NR2B subunit. After the completion of this work, a study appeared demonstrating similar results using an oocyte expression system (Kleckner et al., 1999).

\section{Materials and methods}

\subsection{Cell culture and NMDA receptor expression}

HEK 293 cells obtained from the American Type
Culture Collection were grown in Dulbecco's Modification of Eagle's Medium (Life Technologies) at $37^{\circ} \mathrm{C}$. Cells were split $1-3$ days before transfection and plated at a density of $1-3 \times 10^{5}$ cells/dish in glass-bottomed 35-mm culture dishes (MatTek) coated with Matrigel (Collaborative Biomedical Products). Rat NMDA receptor NR1a subunit cDNA, subcloned into the mammalian cell expression vector pcDM8, was obtained from Dr Robert Wenthold. The NR1a subunit is a splice variant of the NR1 subunit containing the $\mathrm{C} 1$ and $\mathrm{C} 2 \mathrm{C}$-terminal cassettes and lacking $\mathrm{N}$-terminal exon 5. Mammalian cell expression vectors containing NR2A, NR2B and NR2C subunit cDNA were from Dr Peter Seeburg. Cotransfections of the NR1a vector $(1 \mu \mathrm{g} / \mathrm{dish})$ and one of the NR2 vectors $(3 \mu \mathrm{g} / \mathrm{dish})$ were carried out with the $\mathrm{CaPO}_{4}$ method (Chen and Okayama, 1987) in the presence of the NMDA receptor antagonist $( \pm$ )-2-amino-5phosphonopentanoic acid $(200 \mu \mathrm{M})$ to enhance cell survival. An expression vector encoding an enhanced version of green fluorescent protein ( $\mathrm{pS65T}$; Clontech) was included to allow identification of transfected cells $(0.5 \mu \mathrm{g} / \mathrm{dish})$. Cells were incubated with the transfection solution for 16-24 h. Singlecell electrophysiology was performed $48-72 \mathrm{~h}$ following transfection.

\subsection{Electrophysiology}

Whole-cell voltage-clamp recordings were carried out at room temperature on the stage of a Nikon Diaphot inverted microscope. Just prior to recording, the culture medium was replaced with an extracellular recording solution containing $145 \mathrm{mM} \mathrm{NaCl}, 2.5 \mathrm{mM} \mathrm{KCl}, 0.1 \mathrm{mM} \mathrm{CaCl} 2,10$ $\mathrm{mM}$ glucose, $32 \mathrm{mM}$ sucrose and $10 \mathrm{mM}$ HEPES (pH 7.4; 315-320 mOsm). Recording electrodes were pulled from $1.5-\mathrm{mm}$ thin wall glass tubing, fire-polished and filled with intracellular solution containing $145 \mathrm{mM} \mathrm{CsCl}, 1 \mathrm{mM} \mathrm{MgCl}_{2}, 0.1 \mathrm{mM}$ $\mathrm{CaCl}_{2}, 10 \mathrm{mM}$ HEPES, $1 \mathrm{mM}$ EGTA and $17 \mathrm{mM}$ sucrose (pH 7.2; 305-310 mOsm). Electrode resistances were 2-5 M 2 . Current signals were amplified with an Axopatch 200A patch-clamp amplifier (Axon Instruments), filtered at $1 \mathrm{kHz}$ with a low-pass Bessel filter and digitized at 10 $\mathrm{kHz}$ with a Digidata 1200A analog-to-digital con- 
verter (Axon). Series resistance errors were not compensated. Cells expressing the pS65T-encoded fluorescent protein were identified by fluorescence microscopy using an FITC filter system (485 nm excitation and $530 \mathrm{~nm}$ emission).

\subsection{Solution application and dose-response analysis}

Test solutions were applied using a gravity-fed, multibarrel, fast perfusion system, as described previously (Donevan and Rogawski, 1993). The device provides a continuous flow of solution onto the cell under study and allows rapid switching between solutions that exit from a common orifice. During the experiment, fresh bathing solution was continuously applied via the perfusion system. NMDA currents were evoked with $5 \mathrm{~s}$ applications of extracellular recording solution to which $50 \mu \mathrm{M}$ NMDA and $10 \mu \mathrm{M}$ glycine had been added ('NMDA solution'). For construction of dose-response curves, a three-part protocol was used consisting of sequential $5 \mathrm{~s}$ applications of NMDA solution, NMDA plus felbamate, and NMDA alone. Experiments were discarded if the recovery current amplitude was $<90 \%$ of the initial current. Fractional block was determined as $B=1-I_{\mathrm{f}} / I_{\mathrm{c}}$, where $I_{\mathrm{c}}$ is the maximum amplitude of the NMDA current immediately prior to the onset of the felbamate application and $I_{\mathrm{f}}$ is the amplitude of the NMDA-evoked current at the end of $5 \mathrm{~s}$ applications of felbamate. Fractional block was plotted as a function of felbamate concentration, and these data points were fit with the logistic equation

$B=1 /\left\{1+\left([\text { felbamate }] / \mathrm{IC}_{50}\right)^{n_{\mathrm{H}}}\right\}$

where [felbamate] is the concentration of felbamate, $\mathrm{IC}_{50}$ is the theoretical concentration of felbamate producing $50 \%$ inhibition, and $n_{\mathrm{H}}$ is a slope factor having the same significance as the Hill coefficient. Due to inability to reliably solubilize felbamate at concentrations greater than 3 $\mathrm{mM}$, we could not determine the maximal felbamate inhibition. However, the logistic equation used for the fits assumes a theoretical maximal fractional block of 1 . Statistical comparisons were made using PHARM/PCS Version 4.2 (MicroComputer Specialists).

\subsection{Kinetic analysis}

Double exponential growth or decay functions were fit to the current traces using the Levenberg-Marquardt nonlinear curve-fitting function of Origin 5.0 (Microcal Software). Determination of the goodness of fit was made by leastsquares analysis. The decision to reject single exponential fits in favor of double exponential fits was based on comparisons of the mean least squares values using the $t$-test at the 0.05 level of significance.

\subsection{Chemicals}

Felbamate was a gift of Dr R. Duane Sofia (Wallace Laboratories). NMDA was from Research Biochemicals International. All other chemicals were from Sigma Chemical Co.

\section{Results}

\subsection{NMDA responses in transfected cells}

Cells expressing green fluorescent protein and having little or no contact with surrounding cells were chosen for recording. Perfusion with $50 \mu \mathrm{M}$ NMDA ( + $10 \mu \mathrm{M}$ glycine) evoked inward current responses that were $400-2000 \mathrm{pA}$ in amplitude for cells expressing the NR1a/NR2A subunit combination, 100-1000 pA for the NR1a/NR2B subunit combination, and 50-200 pA for the NR1a/NR2C subunit combination.

\subsection{Felbamate block of NMDA receptor currents}

Coapplication of felbamate at concentrations of 0.1-3.0 mM with NMDA $(+10 \mu \mathrm{M}$ glycine $)$ resulted in a dose-dependent reduction in the amplitude of the NMDA-evoked currents in cells expressing the NR1a/NR2A, NR1a/NR2B and NR1a/NR2C subunit combinations (Fig. 1). Onset of block was rapid (less than $1 \mathrm{~s}$ ), and recovery 


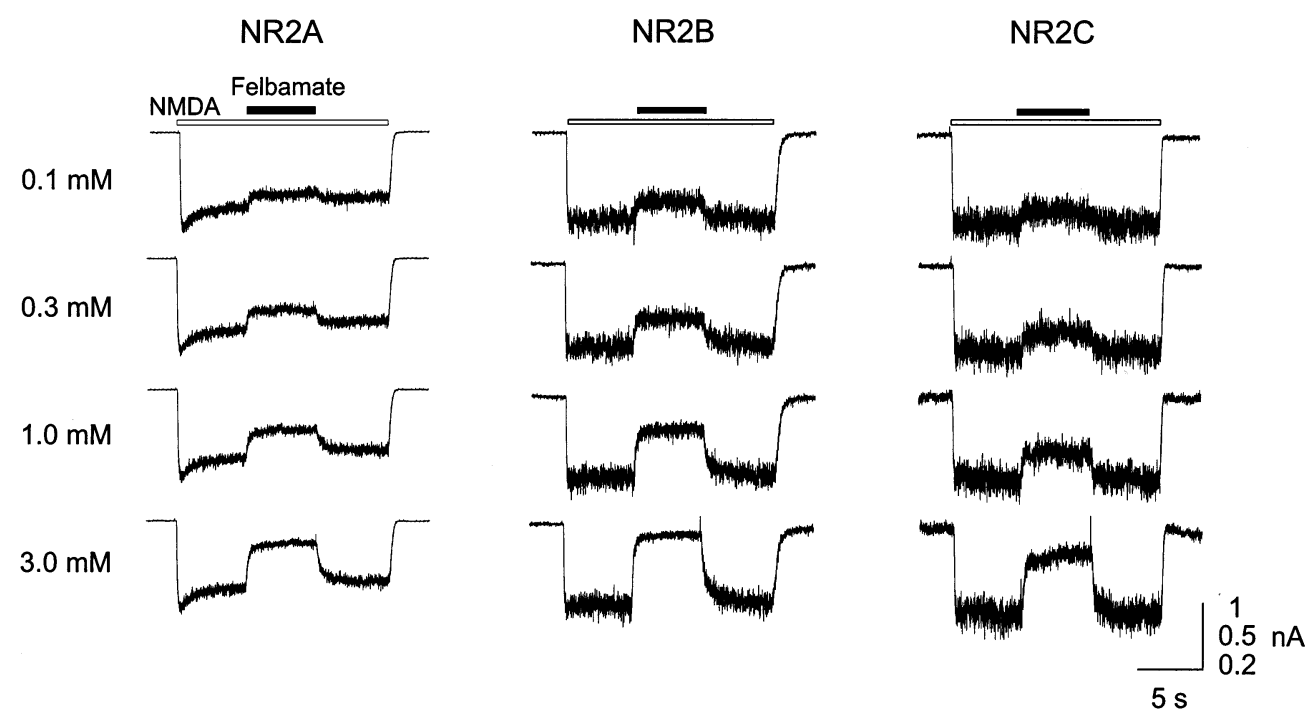

Fig. 1. Felbamate block of inward currents evoked by $50 \mu \mathrm{M}$ NMDA ( + $10 \mu \mathrm{M}$ glycine) in three HEK 293 cells transfected with the NR1a, and either the NR2A, NR2B or NR2C subunits. The period of agonist application is indicated by the open bar. Felbamate at concentrations of $0.1,0.3,1$ and $3 \mathrm{mM}$ was coapplied with the agonist solution during the period indicated by the solid bar. The holding potential was $-60 \mathrm{mV}$. Inward current is downward. The vertical scale bar indicates $1,0.5 \mathrm{and} 0.2 \mathrm{nA}$ for the NR1a/NR2A, NR1a/NR2B and NR1a/NR2C currents, respectively.

from block was essentially complete within 5 s. Qualitatively, at each felbamate concentration, the level of block obtained with the NR1a/NR2 and NR1a/NR2C subunit combinations was similar, whereas there was greater block of currents in the NR1a/NR2B expressing cells.

For each of the three subunit combinations, the fractional block of NMDA receptor currents was assessed in six to eight experiments similar to those of Fig. 1. Fractional block values were determined at the end of $5 \mathrm{~s}$ felbamate coapplications. In each experiment, the fractional block values for felbamate concentrations within the range $0.03-3 \mathrm{mM}$ were plotted as a function of drug concentration and fit according to the logistic equation. The mean $\mathrm{IC}_{50}$ and $n_{\mathrm{H}}$ values from these fits are presented in Table 1. For illustration, the group mean fractional block values are plotted in Fig. 2 with corresponding fits. Felbamate demonstrated modest selectivity for NMDA receptors composed of NR1a/NR2B subunits, while receptors with the NR2A or NR2C subunits had similar affinities for the drug. The relative potencies for NR1a/NR2B were 4.92 versus NR1a/NR2A and 4.62 versus NR1a/NR2C; the relative potency for NR1a/NR2A versus NR1a/

Table 1

Parameters of logistic fits to concentration-fractional block data for felbamate block of recombinant NMDA receptors composed of the NR1a and either the NR2A, NR2B or NR2C subunits $^{\mathrm{a}}$

\begin{tabular}{llll}
\hline $\begin{array}{l}\text { Subunits } \\
\text { NR1a }+)\end{array}$ & $\begin{array}{l}\text { Number of } \\
\text { cells }\end{array}$ & $\mathrm{IC}_{50}(\mathrm{mM})$ & $n_{\mathrm{H}}$ \\
\hline NR2A & 6 & $2.55 \pm 0.57$ & $0.86 \pm 0.04$ \\
NR2B & 8 & $0.52 \pm 0.07$ & $0.70 \pm 0.08$ \\
NR2C & 6 & $2.40 \pm 0.51$ & $0.75 \pm 0.09$ \\
\hline
\end{tabular}

${ }^{\text {a }} \mathrm{IC}_{50}$ and $n_{\mathrm{H}}$ values were determined from individual fits to data for each cell and are presented as group mean \pm S.E.M. By one-way analysis of variance, the mean $\mathrm{IC}_{50}$ value for NR1a/NR2B receptors is significantly different from the values for NR1a/NR2A and NR1a/NR2C $(P<0.01)$, whereas the mean values for NR1a/NR2A and NR1a/NR2C are not significantly different $(P>0.05)$. Mean $n_{\mathrm{H}}$ values are not significantly different from each other but all are significantly $<1$ $(P<0.05$ by confidence limits $)$. 




Fig. 2. Concentration-response relationships for felbamate block of NMDA receptor currents in cells transfected with the NR1a subunit, and either the NR2A, NR2B or NR2C subunits. The data points represent the mean \pm S.D. of steadystate fractional block values obtained $5 \mathrm{~s}$ after the application of felbamate at the indicated concentrations in six to eight cells. The logistic fits to the data points assume complete block at high concentrations. $\mathrm{IC}_{50}\left(n_{\mathrm{H}}\right)$ values for the NR2A, NR2B and NR2C fits were $2.3(0.78), 0.6(0.86)$ and $2.0(0.78)$, respectively.

$\mathrm{NR} 2 \mathrm{C}$ was 1.06 . In each case, the $n_{\mathrm{H}}$ values were significantly $<1$.

\subsection{Kinetics of block}

Time constants for onset and recovery from felbamate block were determined by fitting the current trajectories during onset and recovery from felbamate blocking responses (Fig. 3). Onset of block was not well fit by a single exponential function, but could be adequately fit by the sum of two exponential functions. For felbamate concentrations of $0.3-3 \mathrm{mM}$, the fast time constants were in the range $100-180 \mathrm{~ms}$ and the slow time constants were in the range 500-2000 ms. The fast component typically accounted for $\sim 55 \%$ of the amplitude of the fits. Recovery from block was also better fit by the sum of two exponential functions, with fast time constants in the range $70-200 \mathrm{~ms}$ and slow time constants in the range 400-1200 ms. The fast component typically accounted for about two-thirds of the amplitude of the fits. The fast perfusion system used in these experiments allows solutions changes to be made on the order of $<10 \mathrm{~ms}$ (Donevan and Rogawski, 1993). Consequently, measurements of onset and recovery from block can be used to estimate binding association and dissociation rate constants. Fast and slow association $\left(k_{1 \mathrm{f}}, k_{1 \mathrm{~s}}\right)$ and dissociation $\left(k_{-1 \mathrm{f}}, k_{-1 \mathrm{~s}}\right)$ rate constants for onset and recovery from block for each of the three subunit combinations are summarized in Table 2. It is apparent that the fast and slow association rate constants for the NR1a/NR2B subunit combination are greater than the corresponding rate constants for the NR1a/NR2A and NR1a/NR2C subunit combinations. Similarly, the fast and slow dissociation rate constants for the NR1a/NR2B subunit are slower than those of the other subunit combinations. Assuming that the fast and slow components represent binding to distinct sites, the affinity constants for binding to these sites can be estimated as $K_{\mathrm{D}}=k_{-1} / k_{1}$. The calculated fast and slow affinity constants for each of the three subunit combinations are: NR1a/NR2A, 2.7 and 3.7 $\mathrm{mM}$; NR1a/NR2B, 0.3 and $0.5 \mathrm{mM}$; NR1a/ NR2C, 1.1 and $1.0 \mathrm{mM}$. The kinetically determined affinities at each site compare favorably with the equilibrium affinities determined by dose titration, as summarized in Table 1. Thus, as is the case with equilibrium $\mathrm{IC}_{50}$ values, the kinetically determined binding affinity of felbamate for the NR1a/NR2B subunit combination is higher than for the other two subunit combinations. For each of the subunit combinations, the affinities for the fast and slow sites are comparable. Therefore, at any felbamate concentration, equilibrium block occurs by substantial binding to the sites represented by the fast and slow components.

\section{Discussion}

This study confirms that the antiepileptic drug felbamate is an effective antagonist of NMDA receptors expressed in mammalian cells. The work extends the original demonstration in our laboratory that felbamate blocks native NMDA receptors expressed in rat forebrain and hippocampal cultures (Rho et al., 1994; Subramaniam et al., 1995), and complements a recent study demon- 
strating felbamate block of recombinant NMDA receptors expressed in Xenopus oocytes (Kleckner et al., 1999). This NMDA receptor blocking action of felbamate is in addition to its effects on $\mathrm{GABA}_{\mathrm{A}}$ receptors that occur within the same range of concentrations (Rho et al., 1994, 1997). Felbamate inhibited NMDA receptors composed of the NR1a subunit and either of the NR2A, NR2B or NR2C subunits. However, the drug was modestly more potent as an antagonist of NMDA receptors containing the NR2B subunit. Kinetic analyses of the blocking data demonstrated that the increased affinity of NR1a/NR2B receptors is the result of both enhanced rates of association and diminished rates of dissociation. The absolute and relative potencies for block in the present study (Table 1) compares favorably with those reported for oocyte recordings, where the $\mathrm{IC}_{50}$ values for block of receptors containing the NR2A, NR2B and NR2C subunits were 8.56, 0.93 and 2.02, respectively (Kleckner et al., 1999).

For all three subunit combinations, the blocking action of felbamate occurred in a concentration-dependent fashion. The slope factors in fits to the concentration-block data were less than 1 (Table 1). These fits must be interpreted with caution since fractional block values at high con- centrations were not available due to the limited solubility of the drug. Nevertheless, the low slope factor suggests the existence of more than one blocking site. In line with this possibility, both onset and recovery from block occurred in two exponential phases compatible with drug binding to two distinct blocking sites (or in two distinct orientations to the same binding site where interconversion is not possible). It is interesting that the estimated affinities for binding to the kinetically fast and slow sites were comparable so that equilibrium block occurs by binding to both sites. Although we have interpreted our data under the assumption that all expressed NMDA receptors are identical, it is conceivable that the fast and slow sites could also correspond with distinct NMDA receptors composed of different numbers or configurations of NR1a and NR2 subunits.

Felbamate affinity, as determined in the equilibrium block experiments and also by the kinetic analyses, was greater for the NR1a/NR2B subunit combination than for the other two subunit combinations. The NR2B selectivity of felbamate is shared by a variety of NMDA antagonists, including the phenylethylamine ifenprodil and related compounds such as eliprodil, CP101,606, Ro 25-6981 and nylidrin (Avenet et al., 1997; Brime-
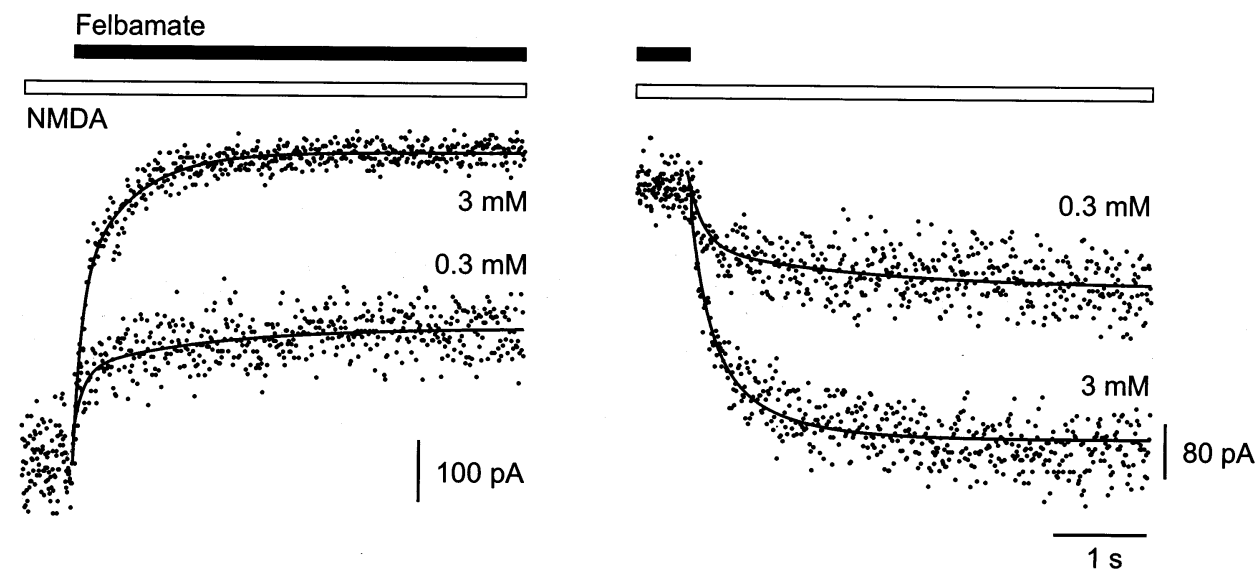

Fig. 3. Onset and recovery from felbamate block of NR1a/NR2B NMDA receptors. Felbamate at concentrations of 0.3 and 3 mM was coapplied with NMDA during the periods indicated by the solid bars. The points following onset (left) or termination (right) of the felbamate applications were fit with second-order exponential functions. The fast and slow time constant values for onset of block were, respectively, 109 and $1471 \mathrm{~ms}$ for $0.3 \mathrm{mM}$ felbamate, and 83 and $574 \mathrm{~ms}$ for $3 \mathrm{mM}$ felbamate; the corresponding values for recovery were 210 and $930 \mathrm{~ms}$, and 150 and $1377 \mathrm{~ms}$. In all cases, the amplitude of the fast component represented $\sim 55 \%$ of the total amplitude. 
Table 2

Rate constants for onset and recovery from felbamate block of recombinant NMDA receptors containing the NR1a subunit and either the NR2A, NR2A or NR2C subunits ${ }^{\mathrm{a}}$

\begin{tabular}{llllll}
\hline Subunits (NR1a +$)$ & \multicolumn{2}{l}{ Onset } & & \multicolumn{2}{l}{ Recovery } \\
\cline { 2 - 3 } \cline { 5 - 6 } & $k_{1 \mathrm{f}}\left(\times 10^{3} \mathrm{~s}^{-1} \mathrm{M}^{-1}\right)$ & $k_{1 \mathrm{~s}}\left(\times 10^{3} \mathrm{~s}^{-1} \mathrm{M}^{-1}\right)$ & & $k_{-1 \mathrm{f}}\left(\mathrm{s}^{-1}\right)$ & $k_{-1 \mathrm{~s}}\left(\mathrm{~s}^{-1}\right)$ \\
\hline NR2A & 3.8 & 0.6 & 1.8 & 5.0 & 2.2 \\
NR2B & 16.2 & 1.1 & 5.5 & 0.9 \\
NR2C & 5.0 & 1.1 & 1.1 \\
\hline
\end{tabular}

\footnotetext{
a Rate constants were determined from double exponential fits to the onset and recovery of felbamate block in three to six cells with felbamate concentrations of $0.3,1.0$ and $3.0 \mathrm{mM}$, except for the NR2C subunit, where the data with $0.3 \mathrm{mM}$ felbamate could not be fit. Forward rate constants were calculated from mean onset time constant values according to the formula $k_{1}=1 /$ ( $\tau_{1}$ [felbamate]), where $\tau_{1}$ is the fast or slow time constant value and [felbamate] is the concentration of felbamate; reverse rate constants were calculated from mean offset time constants as $k_{-1}=1 / \tau_{-1}$. Subscripts $\mathrm{f}$ and $\mathrm{s}$ indicate fast and slow components, respectively. Values at different concentrations were averaged.
}

combe et al., 1997; Fischer et al., 1997; Whittemore et al., 1997; Mott et al., 1998; Mutel et al., 1998; Tamiz et al., 1998), the butyrophenones haloperidol, droperidol and spiperone (Brimecombe et al., 1998; Gallagher et al., 1998; Yamakura et al., 1998), and the novel glycine-site antagonist CGP 61594 (Honer et al., 1998). The fivefold selectivity of felbamate is far less than that of these antagonists. If NR2B selectivity contributes to felbamate's enhanced tolerability in relation to other NMDA receptor antagonists, then these highly selective antagonists might be expected to be particularly favorable as anticonvulsants. There is no evidence that this is the case, possibly because the anticonvulsant utility of many of these more NR2B-selective compounds is hampered by diverse actions on receptors and ion channels unrelated to the NMDA receptor (Ebert et al., 1997; Wlaź et al., 1999). As additional, more specific NR2B-selective agents become available, it will be of interest to examine their anticonvulsant properties to determine if NR2B selectivity is associated with enhanced tolerability for an NMDA receptor blocking anticonvulsant.

Despite several recent studies, the precise mechanism whereby felbamate blocks NMDA receptors is not yet fully understood. Early reports suggested that felbamate may act as a competitive antagonist at the glycine recognition site of NMDA receptors (McCabe et al., 1993; Wamsley et al., 1994). Although various experiments in animal models showing a functional reversal of the anticonvulsant action of felbamate by glycine site ligands were consistent with this possibility (Coffin et al., 1994; White et al., 1995), detailed studies using biophysical methods of analysis have shown conclusively that felbamate is not a glycine site antagonist (Rho et al., 1994; Kanthasamy et al., 1995; Subramaniam et al., 1995; Taylor et al., 1995; Kleckner et al., 1999). Indeed, it has recently been reported that felbamate produces a robust increase in $\left[{ }^{3} \mathrm{H}\right]$ glycine binding to NMDA receptors (McCabe et al., 1998). Thus, while felbamate does not compete at the glycine recognition site, it nevertheless does appear to allosterically modulate glycine site binding.

Single channel recording studies are consistent with a functional channel blocking action of the drug or allosteric effects on channel gating (Rho et al., 1994; Subramaniam et al., 1995). Felbamate is a neutral molecule. Thus, if it were a pore blocker, it would not be expected to exhibit the strong voltage-dependence characteristic of many charged NMDA receptor channel blockers. Indeed, in voltage-clamp recordings, the blocking action of felbamate exhibited minimal (Subramaniam et al., 1995) or no voltage dependence (Kleckner et al., 1999). Detailed analysis of single channel recordings indicated that the predominant action of felbamate is to cause a reduction in the channel open time and burst duration, in association with only a small decrease in single channel amplitude (Rho et al., 1994; Subramaniam et al., 1995). Interestingly, such actions are 
reminiscent of other $\mathrm{NR} 2 \mathrm{~B}$-selective ligands including ifenprodil (Legendre and Westbrook, 1991), CP101,606 (Brimecombe et al., 1997, 1998) and haloperidol (Ilyin et al., 1996; Brimecombe et al., 1998). Whether felbamate blocks NMDA receptors by an allosteric mechanism similar to that of these more selective NR2B antagonists remains to be determined. However, several observations in the recent study of Kleckner et al. (1999) appear to indicate important differences, including the findings: (i) that a mutation of glutamate 201 in NR2B which dramatically decreases the affinity of haloperidol (Gallagher et al., 1998) and CP101,606 (Brimecombe et al., 1998) had only a small effect on felbamate blocking potency; and (ii) that low $\mathrm{pH}$ which markedly enhances ifenprodil and CP101,606 potency (Mott et al., 1998) had no effect on felbamate inhibition of NR1a/NR2B receptors.

In conclusion, NR2B selectivity could in part contribute to felbamate's low neurobehavioral toxicity in relation to other NMDA receptor antagonists, and could also account for its clinical utility in seizure disorders affecting the immature brain. Unlike the NR2A subunit that is distributed ubiquitously in the central nervous system, expression of the NR2B subunit in the adult is largely restricted to the forebrain (Mori and Mishina, 1995). Thus, felbamate may target NMDA receptor-mediated synaptic transmission in forebrain areas critical to seizure generation and avoid perturbing nonforebrain structures that could mediate side effects. The utility of felbamate in childhood epilepsies such as the Lennox-Gastaut syndrome (Anonymous, 1993) may be related to the abundance of NR2B subunits in the developing brain. Thus, the unique pharmacological profile of felbamate as an NMDA receptor antagonist could, in part, contribute to its distinctive clinical characteristics as an anticonvulsant drug.

\section{Acknowledgements}

We are grateful to Karen Wayns for assistance with the cell cultures.

\section{References}

Anonymous, 1993. Efficacy of felbamate in childhood epileptic encephalopathy (Lennox-Gastaut syndrome). The felbamate study group in Lennox-Gastaut syndrome. N. Engl. J. Med. 328, 29-33.

Avenet, P., Léonardon, J., Besnard, F., Graham, D., Depoortere, H., Scatton, B., 1997. Antagonist properties of eliprodil and other NMDA receptor antagonists at rat NR1A/NR2A and NR1A/NR2B receptors expressed in Xenopus oocytes. Neurosci. Lett. 223, 133-136.

Brimecombe, J.C., Boeckman, F.A., Aizenman, E., 1997. Functional consequences of NR2 subunit composition in single recombinant $N$-methyl-D-aspartate receptors. Proc. Natl. Acad. Sci. U.S.A. 94, 11019-11024.

Brimecombe, J.C., Gallagher, M.J., Lynch, D.R., Aizenman, E., 1998. An NR2B point mutation affecting haloperidol and CP101,606 sensitivity of single recombinant $N$-methylD-aspartate receptors. J. Pharmacol. Exp. Ther. 286, 627634.

Chen, C., Okayama, H., 1987. High-efficiency transformation of mammalian cells by plasmid DNA. Mol. Cell. Biol. 7, 2745-2752.

Coffin, V., Cohen-Williams, M., Barnett, A., 1994. Selective antagonism of the anticonvulsant effects of felbamate by glycine. Eur. J. Pharmacol. 256, R9-R10.

Corradetti, R., Pugliese, A.M., 1998. Electrophysiological effects of felbamate. Life Sci. 63, 1075-1088.

Croucher, M.J., Collins, J.F., Meldrum, B.S., 1982. Anticonvulsant action of excitatory amino acid antagonists. Science 216, 899-901.

De Sarro, G., Ongini, E., Bertorelli, R., Aguglia, U., De Sarro, A., 1994. Excitatory amino acid neurotransmission through both NMDA and non-NMDA receptors is involved in the anticonvulsant activity of felbamate in DBA/ 2 mice. Eur. J. Pharmacol. 262, 11-19.

Dingledine, R., Borges, K., Bowie, D., Traynelis, S.F., 1999. The glutamate receptor ion channels. Pharmacol. Rev. 51, $7-61$.

Donevan, S.D., Rogawski, M.A., 1993. GYKI 52466, a 2,3benzodiazepine, is a highly selective, noncompetitive antagonist of AMPA/kainate receptor responses. Neuron 10, $51-59$.

Ebert, U., Wlaź, P., Löscher, W., 1997. Anticonvulsant effects by combined treatment with a glycine ${ }_{B}$ receptor antagonist and a polyamine site antagonist in amygdala-kindled rats. Eur. J. Pharmacol. 322, 179-184.

Fischer, G., Mutel, V., Trube, G., Malherbe, P., Kew, J.N.C., Mohacsi, E., Heitz, M.P., Kemp, J.A., 1997. Ro 25-6981, a highly potent and selective blocker of $N$-methyl-D-aspartate receptors containing the NR2B subunit. Characterization in vitro. J. Pharmacol. Exp. Ther. 283, 1285-1292.

Gallagher, M.J., Huang, H., Lynch, D.R., 1998. Modulation of the $N$-methyl-D-aspartate receptor by haloperidol: NR2B-specific interactions. J. Neurochem. 70, 2120-2128.

Honer, M., Benke, D., Laube, B., Kuhse, J., Heckendorn, R., Allgeier, H., Angst, C., Monyer, H., Seeburg, P.H., Betz, 
H., Mohler, H., 1998. Differentiation of glycine antagonist sites of $N$-methyl-D-aspartate receptor subtypes. J. Biol. Chem. 273, 11158-11163.

Ilyin, V.I., Whittemore, E.R., Guastella, J., Weber, E., Woodward, R.M., 1996. Subtype-selective inhibition of $N$ methyl-D-aspartate receptors by haloperidol. Mol. Pharmacol. 50, 1541-1550.

Kanthasamy, A.G., Matsumoto, R.R., Gunasekar, P.G., Truong, D.D., 1995. Excitoprotective effect of felbamate in cultured cortical neurons. Brain Res. 705, 97-104.

Kleckner, N.W., Glazewski, J.C., Chen, C.C., Moscrip, T.D., 1999. Subtype-selective antagonism of $N$-methyl-D-aspartate receptors by felbamate: insights into the mechanism of action. J. Pharmacol. Exp. Ther. 289, 886-894.

Legendre, P., Westbrook, G.L., 1991. Ifenprodil blocks $N$ methyl-D-aspartate receptors by a two-component mechanism. Mol. Pharmacol. 40, 289-298.

McCabe, R.T., Wasterlain, C.G., Kucharczyk, N., Sofia, R.D., Vogel, J.R., 1993. Evidence for anticonvulsant and neuroprotectant action of felbamate mediated by strychnine-insensitive glycine receptors. J. Pharmacol. Exp. Ther. 264, 1248-1252.

McCabe, R.T., Sofia, R.D., Layer, R.T., Leiner, K.A., Faull, R.L.M., Narang, N., Wamsley, J.K., 1998. Felbamate increases $\left[{ }^{3} \mathrm{H}\right]$ glycine binding in rat brain and sections of human postmortem brain. J. Pharmacol. Exp. Ther. 286, 991-999.

Mori, H., Mishina, M., 1995. Structure and function of the NMDA receptor channel. Neuropharmacology 34, 12191237.

Mott, D.D., Doherty, J.J., Shang, S., Washburn, M.S., Fendley, M.J., Lyuboslavsky, P., Traynelis, S.F., Dingledine, R., 1998. Phenylethanolamines inhibit NMDA receptors by enhancing proton inhibition. Nature Neurosci. 1, 659667.

Mutel, V., Buchy, D., Klingelschmidt, A., Messer, J., Bleuel, Z., Kemp, J.A., Richards, J.G., 1998. In vitro binding properties in rat brain of $\left[{ }^{3} \mathrm{H}\right] \mathrm{Ro} 25-6981$, a potent and selective antagonist of NMDA receptors containing NR2B subunits. J. Neurochem. 70, 2147-2155.

Pellock, J.M., Brodie, M.J., 1997. Felbamate: 1997 update. Epilepsia 38, 1261-1264.

Pisani, A., Stefani, A., Siniscalchi, A., Mercuri, N.B., Bernardi, G., Calabresi, P., 1995. Electrophysiological actions of felbamate on rat striatal neurones. Br. J. Pharmacol. 116, 2053-2061.
Rho, J.M., Donevan, S.D., Rogawski, M.A., 1994. Mechanism of action of the anticonvulsant felbamate: opposing effects on $N$-methyl-D-aspartate and $\gamma$-aminobutyric acid A $_{\text {a }}$ receptors. Ann. Neurol. 35, 229-234.

Rho, J.M., Donevan, S.D., Rogawski, M.A., 1997. Barbiturate-like actions of the propanediol dicarbamates felbamate and meprobamate. J. Pharmacol. Exp. Ther. 280, $1383-1391$.

Rogawski, M.A., 1992. The NMDA receptor, NMDA antagonists and epilepsy therapy. A status report. Drugs 44, 279-292.

Rogawski, M.A., 1998. Mechanism-specific pathways for new antiepileptic drug discovery. Adv. Neurol. 76, 11-27.

Subramaniam, S., Rho, J.M., Penix, L., Donevan, S.D., Fielding, R.P., Rogawski, M.A., 1995. Felbamate block of the $N$-methyl-D-aspartate receptor. J. Pharmacol. Exp. Ther. 273, 878-886.

Tamiz, A.P., Whittemore, E.R., Zhou, Z.-L., Huang, J.-C., Drewe, J.A., Chen, J.-C., Cai, S.-X., Weber, E., Woodward, R.M., Keana, J.F.W., 1998. Structure-activity relationships for a series of bis(phenylalkyl)amines: potent subtype-selective inhibitors of $N$-methyl-D-aspartate receptors. J. Med. Chem. 41, 3499-3506.

Taylor, L.A., McQuade, R.D., Tice, M.A., 1995. Felbamate, a novel antiepileptic drug, reverses $N$-methyl-D-aspartate/ glycine-stimulated increases in intracellular $\mathrm{Ca}^{2+}$ concentration. Eur. J. Pharmacol. Mol. Pharmacol. 289, 229-233.

Wamsley, J.K., Sofia, R.D., Faull, R.L.M., Narang, N., Ary, T., McCabe, R.T., 1994. Interaction of felbamate with $\left[{ }^{3} \mathrm{H}\right] \mathrm{DCKA}-$ labeled strychnine-insensitive glycine receptors in human postmortem brain. Exp. Neurol. 128, 244-250.

White, H.S., Harmsworth, W.L., Sofia, R.D., Wolf, H.H., 1995. Felbamate modulates the strychnine-insensitive glycine receptor. Epilepsy Res. 20, 41-48.

Whittemore, E.R., Ilyin, V.I., Konkoy, C.S., Woodward, R.M., 1997. Subtype-selective antagonism of NMDA receptors by nylidrin. Eur. J. Pharmacol. 337, 197-208.

Wlaź, P., Ebert, U., Löscher, W., 1999. Anticonvulsant effects of eliprodil alone or combined with the glycine $_{\mathrm{B}}$ receptor antagonist L-701,324 or the competitive NDMA antagonist CGP 40116 in the amygdala kindling model in rats. Neuropharmacology 38, 243-251.

Yamakura, T., Sakimura, K., Mishina, M., Shimoji, K., 1998. Sensitivity of the $N$-methyl-D-aspartate receptor channel to butyrophenones is dependent on the $\varepsilon 2$ subunit. Neuropharmacology 37, 709-717. 